University of Nebraska - Lincoln

DigitalCommons@University of Nebraska - Lincoln

Faculty Papers and Publications in Animal

Science

Animal Science Department

2011

Composting or stockpiling of feedlot manure in Nebraska:

Nutrient concentration and mass balance

\author{
Matt K. Luebbe \\ University of Nebraska-Lincoln, mluebbe2@unl.edu \\ G. E. Erickson \\ University of Nebraska-Lincoln, gerickson4@unl.edu \\ T. J. Klopfenstein \\ University of Nebraska-Lincoln, tklopfenstein1@unl.edu \\ Matthew A. Greenquist \\ University of Nebraska, mgreenquist2@unl.edu \\ J. R. Benton \\ University of Nebraska-Lincoln
}

Follow this and additional works at: https://digitalcommons.unl.edu/animalscifacpub

Part of the Animal Sciences Commons

Luebbe, Matt K.; Erickson, G. E.; Klopfenstein, T. J.; Greenquist, Matthew A.; and Benton, J. R., "Composting or stockpiling of feedlot manure in Nebraska: Nutrient concentration and mass balance" (2011). Faculty Papers and Publications in Animal Science. 768.

https://digitalcommons.unl.edu/animalscifacpub/768

This Article is brought to you for free and open access by the Animal Science Department at DigitalCommons@University of Nebraska - Lincoln. It has been accepted for inclusion in Faculty Papers and Publications in Animal Science by an authorized administrator of DigitalCommons@University of Nebraska - Lincoln. 


\title{
$\sqrt{17 r^{3}}$
}

\section{Composting or stockpiling of feedlot manure in Nebraska: Nutrient concentration and mass balance ${ }^{1}$}

\author{
M. K. Luebbe, G. E. Erickson, ${ }^{2}$ PAS, T. J. Klopfenstein, M. A. Greenquist, and J. R. Benton \\ Department of Animal Science, University of Nebraska, Lincoln 68583
}

\begin{abstract}
When feedlot pens are scraped in the spring and summer, manure is often stored before land application can occur in the fall. Manure stockpiled or composted was evaluated for nutrient losses in 2 experiments for 104 (Exp. 1) and $111 d$ (Exp. 2). Stockpiles ( $n=2$ in Exp. 1 and $n=3$ in Exp. 2) and compost windrows $(n=6$ in Exp. 1 and $n=4$ in Exp. 2) were constructed with feedlot manure scraped from pens and sampled upon construction and throughout the storage period. In Exp. 1, $N$ loss was 3 times greater $(P<0.01)$ for compost compared with stockpile on 104 (43.6 and 14.3\%, respectively). Loss of $C$ was $34.7 \%$ greater $(P<0.01)$ for compost compared with stockpile on $d 104$ (54.4 and 40.4\%, respectively). Total mass loss (water + DM) was not different $(P=0.30)$ among storage methods on $d 104$ (20.0 and 15.8\% for compost and stockpile, respectively). In Exp. 2, $N$ loss from compost was 42.1\% greater $(P<0.01)$ compared with stockpiling on d 111. Carbon losses

\footnotetext{
${ }^{1}$ This work is a contribution of the University of Nebraska Agricultural Research Division, supported in part by funds provided through the Hatch Act.

${ }^{2}$ Corresponding author: geericks@unInotes. unl.edu
}

in Exp. 2 were not different $(P=0.77)$ among storage methods on d 111 (38.4 and 37.5\% for compost and stockpile, respectively). Total mass loss in Exp. 2 was less compared with Exp. 1 and was not different $(P=0.23)$ among storage methods (5.7 and 3.6\% for compost and stockpile, respectively). When evaluated on a nutrient basis, stockpiled manure had greater $N$ and $C$ concentrations compared with composted manure.

Key words: compost, finishing cattle, mass balance, nitrogen, stockpile

\section{INTRODUCTION}

Manure removed from cattle feedlot pens in the spring and summer may require storage until crops are harvested in the fall. Composting and stockpiling are 2 methods of manure storage and management available to producers if manure cannot be hauled directly from the pen to nearby fields. These handling and storage methods have an effect on nutrient losses and manure characteristics (Sharpley and Moyer, 2000).

The percent reduction in total mass (water + DM) for composted feedlot manure in Canada with bedding material added to the pen surface can range from 42 to $69 \%$ (Larney et al.,
2006, 2008a,b). The amount of total mass lost under these conditions may make composting a more favorable management method compared with stockpiling manure if $\mathrm{P}$ is to be distributed over more acres to limit the effect on surface water (Wortmann and Walters, 2006). However, greater losses of total mass during composting were reported for experiments at feedlots located in Nebraska and are less than what has been reported in Canada. Eghball et al. (1997) observed total mass losses that ranged from 14.9 to $20.4 \%$ using 3 yr of composting data. Bedding material is not commonly used in feedlots located in Nebraska and southern locations due to warmer conditions (Eghball et al., 1997). If bedding is not used, the management, equipment, land, and labor costs associated with composting may not be offset by the reduction in amount of material that needs to be hauled to the field (Lesoing et al., 1997; Freeze et al., 1999). These factors combined with greater losses of $\mathrm{N}$ and $\mathrm{C}$ for composted manure compared with stockpiled or fresh manure may make composting less feasible in situations in which transportation efficiency is not improved (Larney et al., 2006). The objectives of the current experiments were to 1 ) determine 
chemical and physical properties of composted manure or stockpiled manure and 2) determine nutrient losses over the course of the storage period.

\section{MATERIALS AND METHODS}

The University of Nebraska's Institutional Animal Care and Use Committee approval was not obtained for this study because no animals were used. Manure from open feedlot pens was used to determine the effect of storage method and handling on nutrient changes and mass balance of composted or stockpiled manure. Two studies were conducted during the summer of 2007 and 2008 at the University of Nebraska Agricultural Research and Development Center.

\section{Experiment 1}

In July of 2007, manure from 30 pens of animals fed a common finishing diet ( $>85 \%$ concentrate) was scraped and piled on a cement apron within each pen, sampled (n $=30$ samples per pen), weighed, and hauled to the compost yard (Exp. 1). One composite was made and analyzed for each pen. Manure from 3 pens was used to construct compost windrows for a total of 6 windrow replications. Manure from 6 pens was used to construct 2 stockpiles (2 stockpile replications). Initial windrows and stockpiles contained approximately 12.8 and $25.7 \mathrm{t}$ (wet weight) of manure, respectively. The stockpiles were constructed using a larger amount of manure compared with the compost windrows similar to management practices. Windrows had an initial dimension of $0.9 \mathrm{~m}$ high, $1 \mathrm{~m}$ wide at the base, and $8 \mathrm{~m}$ long. Stockpiles were conical in shape with a base diameter of $6.2 \mathrm{~m}$ and were 2.5 $\mathrm{m}$ high. Windrows were turned using a custom-made windrow turner on $\mathrm{d}$ 14, 42, 59, 69, and 83. The stockpiles were left undisturbed throughout the $104 \mathrm{~d}$ of storage with the exception of when core samples and temperature measurements were taken. Core samples ( $\mathrm{n}=4$ per replication) were taken to a depth of $0.9 \mathrm{~m}$, mixed, subsampled, and frozen at $-4^{\circ} \mathrm{C}$ until analysis. Single samples for each of the 2 stockpile replications and 6 windrow replications were analyzed. Core samples were collected on d 42 , 69,83 , and 104. Temperature was collected at a depth of $1.2 \mathrm{~m}$ in 4 locations on each stockpile or compost replicate 2 to $7 \mathrm{~d}$ following a turn of the compost windrows.

\section{Experiment 2}

In July of 2008, manure from 11 pens was used to construct 3 stockpiles and 4 windrows (Exp. 2). Individual truckloads were weighed and sampled ( $\mathrm{n}=10$ samples per truckload) to determine amount of nutrient contribution from truckload to each stockpile or windrow. Initial windrows and stockpiles contained approximately $64.6 \mathrm{t}$ (wet weight) of manure. Windrows had an initial volume of 1.2 $\mathrm{m}$ high, $1.5 \mathrm{~m}$ wide at the base, and $27 \mathrm{~m}$ long. Stockpiles were conical in shape with a base diameter of $8.5 \mathrm{~m}$ and were $3 \mathrm{~m}$ high. Windrows were turned on d 13, 35, 61, and 89. Core samples were collected on d 36,62 , and 111. Core samples and temperature were collected as described in Exp. 1. The compost was considered mature when the temperature measured did not increase 2 to $7 \mathrm{~d}$ after turning on d 83 for Exp. 1 and d 89 for Exp. 2.

\section{Analysis and Calculations}

Nutrient loss was calculated using ash as an internal marker (Erickson et al., 2001; Larney and Buckley, 2007):

Nutrient loss $\%=1-[(\%$ ash initial $/ \%$ ash final $) \times(\%$ nutrient after $/ \%$ nutrient initial)] $\times 100$.

The total amount of nutrient content was also evaluated in a similar manner using total ash as a marker for DM. Samples were analyzed by a commercial laboratory (Ward Laboratories Inc., Kearney, NE). Manure samples were oven dried for $48 \mathrm{~h}$ at $60^{\circ} \mathrm{C}$ to determine $\mathrm{DM}$ content (AOAC, 1999; method 4.2.03) and ashed, after grinding through a Wiley Mill (1-mm screen; Thomas Scientific, Swedesboro, NJ), at $600^{\circ} \mathrm{C}$ for 6 h (AOAC, 1999; method 4.1.10). Total N (AOAC, 1999; method 4.2.04) was determined using a combustion method N analyzer (Leco FP 2000, Leco Corp., St. Joseph, MI). Nitrate was reduced to nitrite and determined by diazotizing with sulfanilamide followed by coupling with N-(1-naphthyl) ethylenediamine dihydrochloride (Lachat Instruments QuikChem 8500, Milwaukee, WI; $520 \mathrm{~nm}$ ). Ammonium was determined colorimetrically on a 5-g sample after extraction with 100 $\mathrm{mL}$ of $2 \mathrm{~N} \mathrm{KCl}$. Total $\mathrm{P}$ was determined on ashed samples digested (AOAC, 1990; method 648.08) and developed colorimetrically using the molybdovanadate method (AOAC, 1990; method 965.17).

Ammonium $\mathrm{N}$ was measured on samples as-is and after drying for 24 $\mathrm{h}$ in a $100^{\circ} \mathrm{C}$ oven to determine the amount of $\mathrm{N}$ lost when manure is exposed to high temperatures. This estimate of ammonia loss was selected because 35 to $95 \%$ of ammonia is lost in the first 2 to $5 \mathrm{~h}$ following application (Meisinger and Jokela, 2000) and because this method has been used previously to evaluate stockpiled and composted manure (Larney et al., 2006). Organic N was calculated from total $\mathrm{N}$ minus ammonium and nitrate N.

\section{Statistics}

Because of differences among the 2 yr for initial manure nutrient concentration, the number of compost turns, and the number of sampling days, the 2 experiments were analyzed separately. Data were analyzed using the mixed procedure of SAS (SAS Inst. Inc., Cary, NC) with 6 replications for each sampling date for the composted manure and 2 replications for each sampling date for the stockpiled manure in Exp. 1. In Exp. 2, there were 3 replications for stockpile and 4 replications for compost at each sampling date. Factors included in the model were storage method, date of sampling, and the storage method by 
Table 1. Effect of manure storage method on temperature, nutrient concentrations, and ratios in Exp. $1^{1}$

\begin{tabular}{|c|c|c|c|c|c|c|c|c|c|c|c|c|c|}
\hline \multirow[b]{2}{*}{ Item } & \multicolumn{5}{|c|}{ Stockpile, day ${ }^{2}$} & \multicolumn{5}{|c|}{ Compost, day ${ }^{2}$} & \multirow[b]{2}{*}{ SEM $^{3}$} & \multicolumn{2}{|c|}{$P$-value } \\
\hline & 0 & 42 & 69 & 83 & 104 & 0 & 42 & 69 & 83 & 104 & & Int. ${ }^{4}$ & d $104^{5}$ \\
\hline Temperature, ${ }^{\circ} \mathrm{C}$ & 63.3 & 59.7 & 55.8 & 52.2 & 53.1 & 64.6 & 47.7 & 49.0 & 38.8 & 25.7 & & & \\
\hline $\mathrm{DM}, \%$ & 72.5 & 75.6 & 74.3 & 74.2 & 73.8 & 71.2 & 73.2 & 70.0 & 70.0 & 72.6 & 2.8 & 0.78 & 0.61 \\
\hline $\mathrm{OM}, \%$ & $30.1^{a}$ & $21.2^{\mathrm{b}}$ & $19.5^{b c}$ & $18.1^{d}$ & $18.0^{d}$ & $29.6^{a}$ & $18.3^{\mathrm{cd}}$ & $14.4^{\mathrm{e}}$ & $13.9^{\mathrm{ef}}$ & $13.4^{f}$ & 1.3 & $<0.01$ & $<0.01$ \\
\hline Organic C, g/kg & $174.4^{\mathrm{a}}$ & $122.9^{b}$ & $113.1^{b}$ & $104.7^{c}$ & $104.1^{c}$ & $171.5^{\mathrm{a}}$ & $106.3^{b c}$ & $83.3^{d}$ & $80.5^{\text {de }}$ & $77.9^{\mathrm{e}}$ & 8.2 & $<0.01$ & $<0.01$ \\
\hline $\mathrm{P}, \mathrm{g} / \mathrm{kg}$ & 6.28 & 6.72 & 6.72 & 6.68 & 6.81 & 6.46 & 6.42 & 6.28 & 6.07 & 6.11 & 0.35 & 0.41 & 0.04 \\
\hline $\mathrm{C}: \mathrm{N}$ & $13.2^{\mathrm{a}}$ & $11.4^{\mathrm{b}}$ & $10.6^{c}$ & $10.2^{\mathrm{cd}}$ & $9.9^{\text {de }}$ & $12.6^{\mathrm{a}}$ & $11.2^{\mathrm{b}}$ & $10.0^{d}$ & $9.6^{e}$ & $9.7^{\mathrm{de}}$ & 0.4 & 0.05 & 0.68 \\
\hline$N: P$ & $2.26^{\mathrm{a}}$ & $1.85^{b}$ & $1.76^{b}$ & $1.77^{\mathrm{b}}$ & $1.80^{b}$ & $2.26^{a}$ & $1.79^{b}$ & $1.49^{c}$ & $1.43^{c}$ & $1.34^{d}$ & 0.65 & $<0.01$ & $<0.01$ \\
\hline
\end{tabular}

a-fWithin a row, means without a common superscript letter differ $(P<0.05)$.

${ }^{1}$ Values are expressed on a $100 \%$ DM basis.

${ }^{2}$ Day $=$ sampling date from pen cleaning on $\mathrm{d} 0$.

${ }^{3}$ Pooled standard error of the mean.

${ }^{4} F$-test statistic for the storage method by sampling day interaction.

${ }^{5}$ Single degree of freedom contrast of stockpile versus compost on d 104.

sampling date interaction. Sampling date was used as a repeated measure. A single degree of freedom contrast of stockpile and compost on the final sampling day for each experiment was evaluated. The Toeplitz covariance structure was used for nutrient loss data, which included sampling day as a repeated measure, whereas the unstructured covariance structure was used for all other variables, which included sampling day as a repeated measure (Littell et al., 1998). Least squares means were separated using the least significant difference method when a significant $F$-test $(P<0.05)$ was detected. The Proc Corr procedure of SAS was used to determine the relationship between loss of $\mathrm{N}$ and $\mathrm{C}$ within each storage method.

\section{RESULTS AND DISCUSSION}

\section{Temperature}

Temperature of compost measured 2 to $7 \mathrm{~d}$ following turning was considered an indicator of active composting. Temperatures were generally between 40 and $70^{\circ} \mathrm{C}$ with the exception of the final sampling dates in both experiments when temperature failed to elevate after turning of the compost. Composting was considered active when microbial activity was high enough to increase the temperature of the pile to $40^{\circ} \mathrm{C}$ (NRCS, 1992). In Exp. 1, temperatures observed in the stockpiled manure were greater than the thermal kill limit of $55^{\circ} \mathrm{C}$ (NRCS, 1992) until approximately d 69 (Table 1). Compost temperatures elevated to above $55^{\circ} \mathrm{C}$ after construction of the windrows and again after the first 4 turns (data not shown). Stockpiled manure in Exp. 2 remained at temperatures greater than $55^{\circ} \mathrm{C}$ until approximately d 36 (Table 2). Temperatures following compost turns 1 and 2 in Exp. 2 were greater than $55^{\circ} \mathrm{C}$. These results may imply that mean temperatures of manure during this time period are not greatly different during active composting or stockpiling. Temperature within the stockpile likely will increase rapidly during the first days following construction because of high microbial metabolic activity due to the availability of soluble sugars, organic acids, and soluble N (de Bertoldi et al., 1983). The natural insulation properties of feedlot manure also allow for a gradual cooling of the stockpile until energy and $\mathrm{N}$ substrates are exhausted. Turning compost windrows promotes an increase in temperature to thermophilic conditions followed by a decrease until the next turn. During the final turns of compost the rapidly metabolizable substrates are limiting and the pile does not heat up as well (Beffa et al., 1996). The temperature data collected in these experiments indicate stockpiling feedlot manure may be as effective as composting in reducing pathogens.

In addition to parasite and pathogen reduction, several authors have hypothesized that weed seeds are also inactivated when exposed to elevated temperatures during composting (Churchill et al., 1995; Eghball and Power, 1999; El Kader et al., 2007). However, Larney and Blackshaw (2003) determined that only 17 to $29 \%$ of the variation in weed seed viability was accounted for by temperature. Other properties such as short-chain VFA concentration in the manure may also have an effect on seed viability (Shiralipour et al., 1997). Once the oxygen is exhausted during aerobic metabolism, anaerobic conditions exist in the stockpile, which generate short-chain VFA such as acetic acid. These properties may make stockpiling a better management tool for reducing weed seed viability compared with composting.

\section{Dry Matter, Total Mass}

Percent DM of the manure varied with rainfall during the storage period 
Table 2. Effect of manure storage method on temperature, nutrient concentrations, and ratios in Exp. $2^{1}$

\begin{tabular}{|c|c|c|c|c|c|c|c|c|c|c|c|}
\hline \multirow[b]{2}{*}{ Item } & \multicolumn{4}{|c|}{ Stockpile, day ${ }^{2}$} & \multicolumn{4}{|c|}{ Compost, day ${ }^{2}$} & \multirow[b]{2}{*}{ SEM $^{3}$} & \multicolumn{2}{|c|}{$P$-value } \\
\hline & 0 & 36 & 62 & 111 & 0 & 36 & 62 & 111 & & Int. ${ }^{4}$ & d $111^{5}$ \\
\hline Temperature, ${ }^{\circ} \mathrm{C}$ & 65.7 & 55.8 & 35.9 & 26.9 & 69.3 & 60.6 & 42.9 & 31.9 & & & \\
\hline $\mathrm{DM}, \%$ & $67.5^{\mathrm{bc}}$ & $70.0^{\mathrm{b}}$ & $69.3^{\mathrm{bc}}$ & $66.6^{c}$ & $68.7^{\mathrm{bc}}$ & $76.4^{\mathrm{a}}$ & $74.9^{\mathrm{a}}$ & $69.3^{\mathrm{bc}}$ & 1.0 & 0.02 & 0.07 \\
\hline OM, \% & 13.0 & 9.4 & 8.8 & 8.5 & 12.4 & 9.3 & 8.7 & 8.0 & 0.2 & 0.25 & 0.06 \\
\hline Organic C, g/kg & 75.5 & 54.6 & 51.3 & 49.5 & 71.7 & 54.1 & 50.3 & 46.2 & 1.2 & 0.25 & 0.06 \\
\hline$P, g / k g$ & 3.84 & 3.71 & 3.80 & 3.93 & 3.75 & 3.67 & 3.84 & 3.80 & 0.13 & 0.89 & 0.40 \\
\hline $\mathrm{C}: \mathrm{N}$ & 10.9 & 10.4 & 9.7 & 9.3 & 10.7 & 10.0 & 9.3 & 9.3 & 0.2 & 0.39 & 0.40 \\
\hline $\mathrm{N}: \mathrm{P}$ & $1.97^{\mathrm{a}}$ & $1.66^{b}$ & $1.51^{\mathrm{c}}$ & $1.54^{\mathrm{c}}$ & $1.93^{a}$ & $1.54^{\mathrm{c}}$ & $1.44^{c}$ & $1.32^{\mathrm{d}}$ & 0.05 & 0.05 & $<0.01$ \\
\hline
\end{tabular}

a-d Within a row, means without a common superscript letter differ $(P<0.05)$.

${ }^{1}$ Values are expressed on a $100 \%$ DM basis.

${ }^{2}$ Day $=$ sampling date from pen cleaning on $\mathrm{d} 0$.

${ }^{3}$ Pooled standard error of the mean.

${ }^{4} \mathrm{~F}$-test statistic for the storage method by sampling day interaction.

${ }^{5}$ Single degree of freedom contrast of stockpile versus compost on d 111.

in both experiments. The DM content of the initial manure was 71.8 and $68.1 \%$ in Exp. 1 and Exp. 2, respectively (Tables 1 and 2). These values are similar to the average DM content of manure removed from pens during the summer over a 10 -yr period (69.6\%; Kissinger et al., 2006). When compost is turned, the DM content generally increases (Larney et al., 2006, 2008b; El Kader et al., 2007). To ensure adequate moisture of the compost, turning events were timed to coincide with rainfall events during each year. The manure moisture content used in both studies was less than the recommended range (40-60\%; de Bertoldi et al., 1983), but the temperature data indicated active composting did occur. Drymatter losses were not different $(P=$ $0.13)$ among stockpiled and composted manure on d 104 in Exp. 1 and averaged 14.3 and $18.6 \%$, respectively (Table 3). Dry-matter losses in Exp. 2 were low and were not different $(P=$ 0.81 ) among storage methods on the final sampling day (4.9 and 4.8\%, respectively; Table 4). The results from Exp. 1 are similar to DM losses of 14.9 to $20.4 \%$ observed for composted manure by Eghball et al. (1997) at the same experiment station. El Kader et al. (2007) observed greater DM loss for dairy manure turned twice compared with unturned manure (32 and $49 \%$, respectively). Similarly, Larney et al. (2006) observed DM losses of 22.5 and $39.8 \%$ for stockpiled and composted manure, respectively. Total mass loss (water + DM; data not shown) was not different $(P=$ 0.30 ) among storage methods on $\mathrm{d}$ 104 in Exp. 1 but numerically greater for composted manure compared with stockpiled manure (20.0 and $15.8 \%$, respectively). Total mass loss in Exp. 2 was much less compared with Exp. 1 and was not different $(P=0.23)$ among storage methods on d 111 (5.7 and $3.6 \%$ for composted and stockpiled manure, respectively). Most of the total mass loss was in the form of DM because the DM content of the stockpiled manure and composted manure was not different between the initial DM content and final DM content. The values for Exp. 1 are similar to what Eghball et al. (1997) and Wilson et al. (2005) observed for total mass loss in Nebraska as discussed previously.

\section{Carbon}

A significant $(P<0.05)$ storage method by sampling date interaction existed for organic $\mathrm{C}$ concentration and $\mathrm{C}$ loss in Exp. 1 (Tables 1 and 2). Organic $\mathrm{C}$ concentrations were greater
$(P<0.01)$ for stockpiled manure compared with composted manure on sampling d 69 and remained that way until the end of the storage period (Table 1). Loss of $\mathrm{C}$ in Exp. 1 was less $(P<0.01)$ for stockpiled manure compared with composted manure from d 42 until the end of the storage period. Organic $\mathrm{C}$ concentration in Exp. 2 (Table 2$)$ tended $(P=0.06)$ to be greater for stockpiled manure compared with composted manure on d 111 (49.5 and $46.2 \mathrm{~g} / \mathrm{kg}$, respectively). Loss of $\mathrm{C}$ was not different $(P$ $=0.77)$ among treatments in Exp. 2 on d 111 (37.5 and $38.4 \%$ for stockpiled and composted manure, respectively). Initial $\mathrm{C}$ concentrations were approximately 2.3 times greater for the manure used in Exp. 1 compared with Exp. 2 (173.0 and $73.6 \mathrm{~g} / \mathrm{kg}$, respectively). The low $\mathrm{C}$ concentration in Exp. 2 was a result of the high amount of ash in the initial manure $(87.3 \%)$. Pen conditions were very wet and muddy during the winter and spring months before manure removal for Exp. 2. During wet conditions manure and soil on the pen surface are thoroughly mixed causing a greater amount of soil to be removed (Klopfenstein and Erickson, 2002; M. K. Luebbe, G. E. Erickson, T. J. Klopfenstein, and M. A. Greenquist, unpublished data). Using the manure 
Table 3. Effect of manure storage method on DM, organic C, $\mathrm{P}$, and $\mathrm{N}$ mass balance estimates in Exp. ${ }^{1}$

\begin{tabular}{|c|c|c|c|c|c|c|c|c|c|c|c|c|c|}
\hline \multirow[b]{2}{*}{ Item } & \multicolumn{5}{|c|}{ Stockpile, day ${ }^{2}$} & \multicolumn{5}{|c|}{ Compost, day ${ }^{2}$} & \multirow[b]{2}{*}{ SEM $^{3}$} & \multicolumn{2}{|c|}{$P$-value } \\
\hline & 0 & 42 & 69 & 83 & 104 & 0 & 42 & 69 & 83 & 104 & & Int. ${ }^{4}$ & d $104^{5}$ \\
\hline DM loss, \% & 0.0 & 10.9 & 12.8 & 14.4 & 14.3 & 0.0 & 13.7 & 17.8 & 18.2 & 18.6 & 2.7 & 0.72 & 0.13 \\
\hline Organic C loss, $\%$ & $0.0^{d}$ & $29.5^{c}$ & $35.1^{\mathrm{bc}}$ & $39.9^{b}$ & $40.4^{b}$ & $0.0^{d}$ & $37.9^{b}$ & $51.3^{a}$ & $52.9^{a}$ & $54.4^{a}$ & 3.4 & 0.02 & $<0.01$ \\
\hline P loss, $\%$ & 0.0 & -6.5 & -6.5 & -6.3 & -7.8 & 0 & 0.6 & 2.5 & 5.4 & 5.0 & 5.0 & 0.41 & 0.02 \\
\hline Total $\mathrm{N}$ loss, wet, ${ }^{6} \%$ & $0.0^{\mathrm{e}}$ & $12.5^{\mathrm{d}}$ & $17.1^{\mathrm{cd}}$ & $17.1^{\mathrm{cd}}$ & $14.3^{\text {cd }}$ & $0.0^{\mathrm{e}}$ & $21.6^{c}$ & $36.0^{b}$ & $40.6^{\mathrm{ab}}$ & $43.6^{a}$ & 3.9 & $<0.01$ & $<0.01$ \\
\hline Total $\mathrm{N}$ loss, dry, ${ }^{7} \%$ & $0.0^{c}$ & $24.7^{\mathrm{b}}$ & $22.4^{\mathrm{b}}$ & $28.1^{\mathrm{b}}$ & $26.7^{b}$ & $0.0^{c}$ & $30.6^{b}$ & $31.6^{b}$ & $38.6^{a}$ & $40.0^{a}$ & 4.7 & $<0.01$ & $<0.01$ \\
\hline
\end{tabular}

a-e Within a row, means without a common superscript letter differ $(P<0.05)$.

${ }^{1}$ Values are expressed on a $100 \%$ DM basis.

${ }^{2}$ Day $=$ sampling date from pen cleaning on $\mathrm{d} 0$.

${ }^{3}$ Pooled standard error of the mean.

${ }^{4} F$-test statistic for the storage method by sampling day interaction.

${ }^{5}$ Single degree of freedom contrast of stockpile versus compost on d 104.

${ }^{6}$ Samples analyzed wet, values expressed on a 100\% DM basis.

${ }^{7}$ Samples analyzed after drying in a $100^{\circ} \mathrm{C}$ oven for $24 \mathrm{~h}$ to estimate ammonia losses.

scraped from the pen surface on d 0 as a benchmark for $\mathrm{C}$ concentration, stockpiling conserves $\mathrm{C}$ to a greater extent compared with composting and may increase the value of the manure for soil conditioning (Helgason et al., 2005).

Dry-matter and total mass losses observed for both storage treatments in Exp. 2 were less compared with Exp. 1 because of a smaller concentration of $\mathrm{C}$ and $\mathrm{OM}$ in the manure used for each experiment. Percent C loss in Exp. 1 for the compost treat- ment was within the range (44.9 to $61.5 \%$ ) observed by Eghball et al. (1997). In Exp. 1, C loss on d 104 was $35 \%$ greater for composted manure compared with stockpiled manure (54.4 and $40.4 \%$, respectively). The difference between storage methods in Exp. 1 was smaller compared with observations of Thomsen (2000) and Larney et al. (2006) where C loss was approximately 121 and $78 \%$ greater (respectively) for composted manure compared with stockpiled manure. The greater loss of $\mathrm{C}$ may be due to the greater initial $\mathrm{C}$ content of the manure used (445 and $314 \mathrm{mg} / \mathrm{kg}$ for Thomsen et al., 2000, and Larney et al., 2006, respectively). Carbon losses observed by Eghball et al. (1997) would support this hypothesis because initial manure $\mathrm{C}$ concentrations of $197.7,137.4$, and $111.4 \mathrm{~g} / \mathrm{kg}$ were reported to have respective $\mathrm{C}$ losses of $61.5,45.9$, and $44.5 \%$. In contrast to these results, a relationship did not exist between initial $\mathrm{C}$ concentration and percent loss for compost in the experiments conducted by Larney

Table 4. Effect of manure storage method on DM, organic C, $\mathrm{P}$, and $\mathrm{N}$ mass balance estimates in Exp. $\mathbf{2}^{1}$

\begin{tabular}{|c|c|c|c|c|c|c|c|c|c|c|c|}
\hline \multirow[b]{2}{*}{ Item } & \multicolumn{4}{|c|}{ Stockpile, day ${ }^{2}$} & \multicolumn{4}{|c|}{ Compost, day ${ }^{2}$} & \multirow[b]{2}{*}{ SEM $^{3}$} & \multicolumn{2}{|c|}{$P$-value } \\
\hline & 0 & 36 & 62 & 111 & 0 & 36 & 62 & 111 & & Int. ${ }^{4}$ & d $111^{5}$ \\
\hline DM loss, \% & 0.0 & 4.0 & 4.6 & 4.9 & 0.0 & 3.3 & 4.0 & 4.8 & 0.5 & 0.76 & 0.81 \\
\hline Organic C loss, \% & 0.0 & 30.4 & 35.2 & 37.5 & 0.0 & 26.8 & 32.4 & 38.4 & 3.2 & 0.70 & 0.77 \\
\hline P loss, $\%$ & 0.0 & 7.1 & 5.0 & 3.0 & 0.0 & 6.3 & 2.4 & 4.2 & 5.2 & 0.96 & 0.81 \\
\hline Total N loss, wet, $6 \%$ & 0.0 & 21.5 & 27.1 & 24.2 & 0 & 25.2 & 27.4 & 34.4 & 3.4 & 0.14 & $<0.01$ \\
\hline Total N loss, dry, ${ }^{7} \%$ & 0.0 & 24.9 & 32.1 & 29.5 & 0 & 28.2 & 29.5 & 35.0 & 3.2 & 0.33 & 0.10 \\
\hline
\end{tabular}

${ }^{1}$ Values are expressed on a $100 \%$ DM basis.

${ }^{2}$ Day $=$ sampling date from pen cleaning on $\mathrm{d} 0$.

${ }^{3}$ Pooled standard error of the mean.

${ }^{4} F$-test statistic for the storage method by sampling day interaction.

${ }^{5}$ Single degree of freedom contrast of stockpile versus compost on d 111.

${ }^{6}$ Samples analyzed wet, values expressed on a $100 \%$ DM basis.

${ }^{7}$ Samples analyzed after drying in a $100^{\circ} \mathrm{C}$ oven for $24 \mathrm{~h}$ to estimate ammonia losses. 
et al. (2008a) and Zvomuya et al. (2005). If the percent loss is similar for manure with different $\mathrm{C}$ concentrations, the total amount $(\mathrm{kg})$ of $\mathrm{C}$ lost will be greater for manure with a greater initial concentration of $\mathrm{C}$. If a greater amount of $\mathrm{C}$ is lost, composting may be more desirable compared with stockpiling manure if one of the goals is to reduce total mass and improve transportation efficiency to the field.

The greatest loss of DM and C occurred between construction of the windrows or stockpiles and the first sampling date. When data were evaluated on a percentage loss per day basis, the results remained the same (data not shown). The loss of $\mathrm{DM}$ and $\mathrm{C}$ was similar among storage methods in Exp. 2 during that time. Larney et al. (2008b) observed similar results with greater water, DM, and C losses from initiation of the experiment to an interim period compared with losses from the interim period until the end of active composting. Oxygen trapped in the stockpile during pen scraping and construction may allow for conditions favorable for aerobic bacteria to degrade $\mathrm{C}$ similar to composting. These factors may help to explain why a large amount of nutrients is lost early on during the storage period for both methods.

\section{Phosphorus}

Concentration of $\mathrm{P}$ was greater $(P$ $=0.04)$ for stockpiled manure compared with composted manure on d 104 in Exp. 1 (6.81 and $6.11 \mathrm{~g} /$ $\mathrm{kg}$, respectively; Table 1 ). In addition, $\mathrm{P}$ loss was greater $(P=0.02)$ for composted manure compared with stockpiled manure on d $104(5.0$ and $-7.8 \%$, respectively; Table 3 ). Concentration of $\mathrm{P}$ was not different among storage methods in Exp. 2 on $111(P=0.40$; Table 2$)$. The range in $\mathrm{P}$ loss reported by Eghball et al. (1997) was from -8.8 to $12.4 \%$. Parkinson et al. (2004) observed P losses of $12 \%$ for stockpiled manure and higher losses for compost turned once or 3 times (28 and $27 \%$, respectively). Similarly, Larney et al. (2006) observed P loss to be numerically less for stockpiled manure compared with composed manure $(6.7$ and $30.0 \%$, respectively). Among replicates in the experiment of Larney et al. (2006), $\mathrm{P}$ loss ranged from -23.1 to $60.0 \%$. Negative estimates for P loss indicate a net gain of the nutrient. These results may be due to the sampling procedure and errors associated with measuring small nutrient concentrations. Because $\mathrm{P}$ does not volatilize, as DM volume and mass decrease, the concentration of $\mathrm{P}$ should increase. However, the concentration of $\mathrm{P}$ did not increase in either of the current studies. One explanation for low $\mathrm{P}$ losses in the current experiments may be precipitation (runoff of $\mathrm{P}$ ) and the solubility of $\mathrm{P}$ in these experiments. Bremer et al. (2008) reported the water-extractable $\mathrm{P}$ in manure averaged $24 \%$ for diets that ranged in $\mathrm{P}$ content from 1.0 to $4.9 \mathrm{~g} / \mathrm{kg}$. This may be one explanation why composted manure had a greater $\mathrm{P}$ loss in Exp. 1 compared with the stockpiled manure on d 104.

\section{Nitrogen}

The largest loss of $\mathrm{N}$ occurred from the time of pen scraping to the first sampling date for both storage methods in Exp. 1 and 2 (Tables 5 and 6 , respectively). The final manure $\mathrm{N}$ concentration was $48.8 \%$ greater $(P<$ 0.01 ) for stockpiled manure compared with composted manure on d 104 in Exp. 1 (12.2 and $8.2 \mathrm{~g} / \mathrm{kg}$, respectively; Table 5). In Exp. 2, the difference between stockpiled and composted manure was not as large as in Exp. 1 (18.0\%) but was greater $(P<0.01)$ for stockpiled manure compared with composted manure on d 111 (5.9 and $5.0 \mathrm{~g} / \mathrm{kg}$, respectively; Table 6$)$. Total $\mathrm{N}$ loss in Exp. 1 (Table 3) for composted manure was greater $(P<0.01)$ on d 42 compared with stockpiled manure and remained that way through the last sampling date. Nitrogen loss in stockpiled manure did not increase after d 42 (sampling d 69, 83, and 104 in Exp. 1). Loss of $\mathrm{N}$ in Exp. 1 for composted manure increased from d 42 to 69 and again from d 69 to 104 .
In Exp. 2 loss of $\mathrm{N}$ (wet basis; Table 4) was less $(P<0.01)$ for stockpiled manure compared with composted manure on d 111 (24.2 and 34.4\%, respectively).

The main pathway for $\mathrm{N}$ loss during handling, storage, and spreading is ammonia volatilization (Kirchmann and Witter, 1989; Hao et al., 2001). Samples that were dried completely had less $(P<0.01)$ total $\mathrm{N}$ concentrations compared with samples that were analyzed wet. Total $\mathrm{N}$ concentration in Exp. 1 for dry samples (Table $5)$ was greater $(P<0.01)$ for stockpiled manure compared with composted manure by d 42 and remained that way throughout the storage period. These results are similar to those observed when the samples were analyzed wet. Concentration of total $\mathrm{N}$ for dry samples on d 104 was $30.5 \%$ greater $(P<0.01)$ for stockpiled manure compared with composted manure. This is a smaller difference compared with the wet $\mathrm{N}$ analysis, in which concentration of $\mathrm{N}$ was $48.8 \%$ greater in the stockpile. These differences are a result of the ammonium $\mathrm{N}$ concentration for stockpiled manure samples being greater than that of composted manure samples on d 104. Even though N loss using oven-dried samples increased $87 \%$ for stockpiled manure compared with the wet analysis, composted manure $\mathrm{N}$ loss remained $50 \%$ greater $(P<0.01)$ compared with stockpiled manure on d 104.

In Exp. 2 dried samples had reduced $(P<0.01) \mathrm{N}$ concentrations compared with samples that were analyzed wet (Table 6). The difference in $\mathrm{N}$ concentration and percent $\mathrm{N}$ loss for wet and dry samples in Exp. 2 were smaller in magnitude compared with the differences in Exp. 1. These results may be due to the lesser amount of total $\mathrm{N}$ for the initial samples. Even though the differences among treatments were less for Exp. 2 compared with Exp. 1, total N concentration was $12.8 \%$ greater $(P<$ 0.01 ) for stockpiled manure compared with composted manure on d 111.

Total $\mathrm{N}$ losses in these experiments for stockpiled and composted ma- 
Table 5. Effect of manure storage method and laboratory analysis on nitrogen concentration and recoveries in Exp. $1^{1}$

\begin{tabular}{|c|c|c|c|c|c|c|c|c|c|c|c|c|c|}
\hline \multirow[b]{2}{*}{ Item } & \multicolumn{5}{|c|}{ Stockpile, day ${ }^{2}$} & \multicolumn{5}{|c|}{ Compost, day ${ }^{2}$} & \multirow[b]{2}{*}{ SEM $^{3}$} & \multicolumn{2}{|c|}{$P$-value } \\
\hline & 0 & 42 & 69 & 83 & 104 & 0 & 42 & 69 & 83 & 104 & & Int. ${ }^{4}$ & d $104^{5}$ \\
\hline \multicolumn{14}{|l|}{$\begin{array}{l}\text { Wet laboratory } \\
\text { analysis }^{6}\end{array}$} \\
\hline Total N, g/kg & $14.2^{\mathrm{a}}$ & $12.4^{\mathrm{abc}}$ & $11.8^{\mathrm{bc}}$ & $11.8^{\mathrm{bc}}$ & $12.2^{\mathrm{bc}}$ & $14.6^{\mathrm{a}}$ & $11.5^{c}$ & $9.3^{d}$ & $8.7^{\mathrm{e}}$ & $8.2^{\mathrm{e}}$ & 1.0 & $<0.01$ & $<0.01$ \\
\hline Ammonium, g/kg & $1.10^{c}$ & $2.30^{\mathrm{ab}}$ & $1.85^{\mathrm{b}}$ & $2.00^{\mathrm{ab}}$ & $2.40^{\mathrm{a}}$ & $1.07^{c}$ & $2.37^{a}$ & $0.35^{\mathrm{e}}$ & $0.62^{d}$ & $0.35^{\mathrm{e}}$ & 0.24 & $<0.01$ & $<0.01$ \\
\hline Ammonium, $\%$ total $\mathrm{N}$ & $7.9^{c}$ & $18.2^{\mathrm{ab}}$ & $15.8^{\mathrm{b}}$ & $17.1^{\mathrm{ab}}$ & $19.0^{\mathrm{a}}$ & $7.3^{c}$ & $20.5^{a}$ & $3.7^{\mathrm{d}}$ & $7.2^{\mathrm{c}}$ & $4.2^{\mathrm{d}}$ & 0.9 & $<0.01$ & $<0.01$ \\
\hline Organic N, g/kg & 13.1 & 10.1 & 9.9 & 9.6 & 9.6 & 13.6 & 9.1 & 7.8 & 7.8 & 7.4 & 1.0 & 0.17 & $<0.01$ \\
\hline Organic $\mathrm{N}, \%$ total $\mathrm{N}$ & $91.9^{\mathrm{ab}}$ & $81.6^{b}$ & $83.4^{c}$ & $81.7^{c}$ & $78.5^{\mathrm{d}}$ & $92.7^{a}$ & $79.5^{d}$ & $94.6^{\mathrm{a}}$ & $89.9^{b}$ & $90.2^{\mathrm{b}}$ & 3.1 & $<0.01$ & $<0.01$ \\
\hline Nitrate $\mathrm{N}, \mathrm{mg} / \mathrm{kg}$ & 0 & 0 & 50 & 113 & 300 & 0 & 0 & 133 & 250 & 450 & 105 & 0.57 & 0.13 \\
\hline \multicolumn{14}{|l|}{$\begin{array}{l}\text { Dry laboratory } \\
\text { analysis }^{7}\end{array}$} \\
\hline Total N, g/kg & $13.4^{\mathrm{a}}$ & $10.9^{b}$ & $10.8^{\mathrm{bc}}$ & $10.4^{\mathrm{bcd}}$ & $10.7^{\mathrm{bcd}}$ & $13.8 a$ & $9.6^{\mathrm{cd}}$ & $9.3^{d}$ & $8.4^{\mathrm{e}}$ & $8.2^{\mathrm{e}}$ & 0.7 & 0.01 & $<0.01$ \\
\hline Ammonium, g/kg & $0.32^{\mathrm{e}}$ & $0.82^{\mathrm{a}}$ & $0.87^{a}$ & $0.67^{b}$ & $0.90^{\mathrm{a}}$ & $0.29^{f}$ & $0.47^{\circ}$ & $0.44^{\mathrm{cd}}$ & $0.42^{\mathrm{cd}}$ & $0.38^{\mathrm{de}}$ & 0.07 & $<0.01$ & $<0.01$ \\
\hline Ammonium, $\%$ total $\mathrm{N}$ & 2.3 & 6.5 & 7.3 & 5.6 & 7.4 & 1.9 & 4.2 & 3.7 & 4.9 & 4.2 & 1.2 & 0.12 & $<0.01$ \\
\hline
\end{tabular}

a-fWithin a row, means without a common superscript letter differ $(P<0.05)$.

${ }^{1}$ Values are expressed on a $100 \%$ DM basis.

${ }^{2}$ Day $=$ sampling date from pen cleaning on $\mathrm{d} 0$.

${ }^{3}$ Pooled standard error of the mean.

${ }^{4} \mathrm{~F}$-test statistic for the storage method by sampling day interaction.

${ }^{5}$ Single degree of freedom contrast of stockpile versus compost on d 104.

${ }^{6}$ Samples analyzed wet, values expressed on a $100 \%$ DM basis.

${ }^{7}$ Samples analyzed after drying in a $100^{\circ} \mathrm{C}$ oven for $24 \mathrm{~h}$ to estimate ammonia losses.

Table 6. Effect of manure storage method and laboratory analysis on nitrogen concentration in Exp. ${ }^{1}$

\begin{tabular}{|c|c|c|c|c|c|c|c|c|c|c|c|}
\hline \multirow[b]{2}{*}{ Item } & \multicolumn{4}{|c|}{ Stockpile, day ${ }^{2}$} & \multicolumn{4}{|c|}{ Compost, day ${ }^{2}$} & \multirow[b]{2}{*}{ SEM $^{3}$} & \multicolumn{2}{|c|}{$P$-value } \\
\hline & 0 & 36 & 62 & 111 & 0 & 36 & 62 & 111 & & Int. ${ }^{4}$ & d $111^{5}$ \\
\hline \multicolumn{12}{|l|}{ Wet laboratory analysis ${ }^{6}$} \\
\hline Total N, g/kg & $7.6^{\mathrm{a}}$ & $6.2^{\mathrm{b}}$ & $5.9^{\mathrm{bc}}$ & $5.9^{\mathrm{bc}}$ & $7.3^{\mathrm{a}}$ & $5.6^{c}$ & $5.5^{\mathrm{c}}$ & $5.0^{d}$ & 0.2 & $<0.01$ & $<0.01$ \\
\hline Ammonium, g/kg & $0.89^{a b}$ & $1.45^{\mathrm{a}}$ & $1.12^{\mathrm{a}}$ & $1.35^{\mathrm{a}}$ & $0.86^{\mathrm{ab}}$ & $0.58^{\mathrm{bc}}$ & $0.44^{c}$ & $0.31^{c}$ & 0.12 & $<0.01$ & $<0.01$ \\
\hline Ammonium, $\%$ total $\mathrm{N}$ & $11.8^{b}$ & $23.0^{\mathrm{a}}$ & $19.3^{\mathrm{a}}$ & $22.4^{\mathrm{a}}$ & $11.8^{b}$ & $10.2^{\mathrm{bc}}$ & $8.0^{c}$ & $6.3^{c}$ & 1.6 & $<0.01$ & $<0.01$ \\
\hline Organic N, g/kg & $6.7^{a}$ & $4.7^{\mathrm{bc}}$ & $4.5^{\mathrm{cd}}$ & $4.5^{\mathrm{cd}}$ & $6.4^{a}$ & $4.9^{\mathrm{b}}$ & $4.6^{\mathrm{cd}}$ & $4.2^{\mathrm{e}}$ & 0.1 & 0.03 & 0.08 \\
\hline Organic N, \% total $\mathrm{N}$ & $88.3^{a}$ & $76.4^{c}$ & $78.5^{c}$ & $74.0^{d}$ & $88.5^{\mathrm{a}}$ & $87.3^{\mathrm{ab}}$ & $83.1^{\mathrm{b}}$ & $84.7^{\mathrm{b}}$ & 1.6 & $<0.01$ & $<0.01$ \\
\hline Nitrate $\mathrm{N}, \mathrm{mg} / \mathrm{kg}$ & $0^{d}$ & $33^{d}$ & $133^{b c}$ & $216^{b}$ & $0^{d}$ & $100^{\mathrm{bcd}}$ & $500^{a}$ & $475^{a}$ & 57 & $<0.01$ & $<0.01$ \\
\hline \multicolumn{12}{|l|}{ Dry laboratory analysis ${ }^{7}$} \\
\hline Total N, g/kg & 7.2 & 5.6 & 5.2 & 5.3 & 6.9 & 5.1 & 5.0 & 4.7 & 0.2 & 0.06 & $<0.01$ \\
\hline Ammonium, g/kg & $0.37^{d}$ & $0.55^{b c}$ & $0.68^{\mathrm{ab}}$ & $0.71^{a}$ & $0.37^{d}$ & $0.47^{c}$ & $0.43^{\text {cd }}$ & $0.31^{\mathrm{e}}$ & 0.06 & $<0.01$ & $<0.01$ \\
\hline Ammonium, $\%$ total $\mathrm{N}$ & $5.1^{d}$ & $9.9^{b}$ & $13.3^{a}$ & $13.3^{a}$ & $5.4^{d}$ & $9.3^{b}$ & $8.5^{\mathrm{bc}}$ & $6.6^{c}$ & 1.2 & $<0.01$ & $<0.01$ \\
\hline
\end{tabular}

a-eWithin a row, means without a common superscript letter differ $(P<0.05)$.

${ }^{1}$ Values are expressed on a $100 \%$ DM basis.

${ }^{2}$ Day $=$ sampling date from pen cleaning on $\mathrm{d} 0$.

${ }^{3}$ Pooled standard error of the mean.

${ }^{4} F$-test statistic for the storage method by sampling day interaction.

${ }^{5}$ Single degree of freedom contrast of stockpile versus compost on d 111.

${ }^{6}$ Samples analyzed wet, values expressed on a 100\% DM basis.

${ }^{7}$ Samples analyzed after drying in a $100^{\circ} \mathrm{C}$ oven for $24 \mathrm{~h}$ to estimate ammonia losses. 
nure are similar to what Larney et al. (2006) observed for the 2 storage methods. When Larney et al. (2006) evaluated total $\mathrm{N}$ loss on wet samples, composted manure had greater losses compared with stockpiled manure (54.5 and $21.7 \%$, respectively). When the samples were dried down, $\mathrm{N}$ losses remained greater for compost compared with stockpiling (46.3 and $22.5 \%$, respectively). It is reasonable to assume the differences for total $\mathrm{N}$ in wet samples and dry samples is due to the loss of ammonia. Nitrogen in the form of $\mathrm{N}_{2} \mathrm{O}$ was not measured in the current experiments, but previous observations for $\mathrm{N}_{2} \mathrm{O}$ losses from manure suggest a small effect on total $\mathrm{N}$ loss (Hao et al., 2004; El Kader et al., 2007).

In Exp. 1, ammonium N (Table 5) for the initial manure samples averaged $7.6 \%$ of total $\mathrm{N}$ and increased $(P<0.01)$ for both treatments to 18.2 and $20.5 \%$ on d 42 for stockpiled and composted manure, respectively. Ammonium $\mathrm{N}$ remained at greater ( $>15 \%$ of total N; $P<0.01$ ) concentrations than those observed on $\mathrm{d} 42$ for stockpiled manure, and a decrease was observed for composted manure after d 42. Ammonium $\mathrm{N}$ for initial manure in Exp. 2 (Table 6) averaged $11.8 \%$ of total $\mathrm{N}$ and increased for stockpiled manure on $\mathrm{d} 36$. The level of ammonium $\mathrm{N}$ in stockpiled manure remained at levels greater than the initial or fresh manure throughout the $111 \mathrm{~d}$ of storage. Conversely, the proportion of ammonium $\mathrm{N}$ for composted manure decreased from d 36 until d 111. The results for the composted manure in Exp. 1 are similar to what was observed by Larney et al. (2008b) with a rapid increase in percent ammonium followed by a gradual decline to $3 \%$ of total N. For the comparison of stockpiled and composted manure, Larney et al. (2006) observed the proportion of ammonium $\mathrm{N}$ to be less for compost compared with stockpiled manure after storage (3 and 15\%, respectively). Similarly, El Kader et al. (2007) observed high ammonia emissions initially upon construction of the stockpile or windrows, but there was not an increase after the com- posted manure was turned compared with stockpiled manure.

Nitrate N numerically increased for both storage methods in Exp. 1 (Table 5) from 0 to $300 \mathrm{mg} / \mathrm{kg}$ in the stockpiled manure and from 0 to 450 $\mathrm{mg} / \mathrm{kg}$ for composted manure. The increase in nitrate $\mathrm{N}$ in Exp. 2 (Table $6)$ was greater $(P<0.01)$ for compost compared with stockpiled manure. In Exp. 2, manure nitrate concentrations were 216 and $475 \mathrm{mg} / \mathrm{kg}$ for stockpiled and composted manure, respectively, on d 111 . These results are similar to the numeric differences observed by Larney et al. (2006) in which composted manure had greater nitrate concentrations compared with stockpiled manure (377 and $240 \mathrm{mg} /$ $\mathrm{kg}$, respectively). Greater $\mathrm{NO}_{3}-\mathrm{N}$ and lesser $\mathrm{NH}_{4}-\mathrm{N}$ concentrations in composted manure compared with both stockpiled and initial manure in the current experiments is a result of nitrification. Available N (ammonium N and nitrate $\mathrm{N}$ ratio) provides a simple index for compost maturity (Bernai et al., 1998; Helgason et al., 2005). The $\mathrm{NH}_{4}: \mathrm{NO}_{3}$ ratio for composted manure was $<1$ on d 104 in Exp. 1 and on d 62 and d 111 in Exp. 2. Another indicator of compost maturity is ammonium N concentrations $<0.4 \mathrm{~g} / \mathrm{kg}$ (Bernai et al., 1998), which was also observed for compost in both experiments on the final sampling day.

Carbon and $\mathrm{N}$ losses were positively correlated $(P<0.01)$ for composted manure in Exp. 1 and Exp. $2(\mathrm{r}=$ 0.93 and 0.89 , respectively). These results are similar to those observed by Eghball et al. (1997) in which initial C:N ratios of 12 to 17 were found to be correlated $(\mathrm{r}=0.78)$ to the amount of $\mathrm{N}$ loss. When the C:N ratio of manure on the pen surface is increased by feeding a less digestible energy source, $\mathrm{N}$ losses are reduced. Bierman et al. (1999) and Erickson and Klopfenstein (2001) observed a relationship for the amount of $\mathrm{OM}$ and $\mathrm{N}$ in the manure during pen cleaning $\left(\mathrm{R}^{2}=0.90\right.$ and 0.86 , respectively). Transformations of $\mathrm{N}$ on the pen surface are similar to those during composting due to aerobic conditions in the compost. The relationship between $\mathrm{C}$ and $\mathrm{N}$ losses for stockpiled manure tended $(\mathrm{r}=0.68, P=0.06)$ to be correlated in Exp. 1, whereas a relationship did not exist for Exp. 2 (r $=0.49, P=0.18)$. These observations are similar to those of Kirchmann and Witter (1989) in which manure C:N ratios of 18,24 , and 36 resulted in ammonia release (as a percent of $\mathrm{N}$ initially present) of 44,18 , and $9 \%$ in composted manure. Using the same $\mathrm{C}: \mathrm{N}$ ratios under anaerobic conditions, the authors did not observe an effect on ammonia losses $(<1 \%)$. Larney et al. (2006) combined both storage methods to predict $\mathrm{N}$ loss and concluded that $86 \%$ of the variability was explained by $\mathrm{C}$ loss.

\section{IMPLICATIONS}

A stronger relationship for $\mathrm{C}$ and $\mathrm{N}$ loss existed with composted manure compared with stockpiled manure, which may be due in part to the differences in $\mathrm{N}$ and $\mathrm{C}$ mineralization rates among the 2 storage methods. When compared on a crop nutrient basis, stockpiled feedlot manure has a greater nutrient value than does composted manure. Similar DM losses and moisture content of the 2 storage methods indicate volume and weight are not substantially influenced with either method. Added costs for management, labor, land, and equipment needed for composting may not be offset by a decrease in transportation cost to the field. When these factors are coupled with nutrient loss, stockpiling of feedlot manure may be more economically favorable. However, to determine the most appropriate methods for conserving nutrients from feedlot manure, land application and mass balance estimates in the field receiving the manure need to be evaluated.

\section{LITERATURE CITED}

AOAC. 1990. Official Methods of Analysis. 15th ed. AOAC, Arlington, VA.

AOAC. 1999. Official Methods of Analysis of AOAC International. 16th ed., 5th ed., 5th rev. P. Cunniff, ed. AOAC Int., Gaithersburg, MD. 
Beffa, T., M. Blanc, L. Marilley, J. L. Fischer, P. F. Lyon, and M. Aragno. 1996. Taxonomic and metabolic microbial diversity during composting. p. 149 in The Science of Composting Part 1. M. de Bertoldi, P. Sequi, B. Lemmes, and T. Papi, ed. Blackie Academic and Professional, London, UK.

Bernai, M. P., C. Paredes, M. A. SanchezMonedero, and J. Cegarra. 1998. Maturity and stability parameters of composts prepared with a wide range of organic wastes. Bioresour. Technol. 63:91.

Bierman, S., G. E. Erickson, T. J. Klopfenstein, R. A. Stock, and D. H. Shain. 1999. Evaluation of nitrogen and organic matter balance in the feedlot as affected by level and source of dietary fiber. J. Anim. Sci. $77: 1645$.

Bremer, V. R., C. B. Buckner, G. E. Erickson, and T. J. Klopfenstein. 2008. Total and water soluble phosphorus content of feedlot cattle feces and manure. Nebraska Beef Cattle Rep. MP 91:62.

Churchill, D. B., S. C. Alderman, G. W. Mueller-Warrant, L. F. Elliott, and D. N. Bilsland. 1995. Survival of weed seeds and seed pathogen propagates in composted grass seed straw. Appl. Eng. Agric. 12:57.

de Bertoldi, M., G. Villini, and A. Pera. 1983. The biology of composting: A review. Waste Manag. Res. 1:157.

Eghball, B., and J. F. Power. 1999. Composted and noncomposted manure application to conventional and no-tillage systems: Corn yield and nitrogen uptake. Agron. J. 91:819.

Eghball, B., J. F. Power, J. E. Gilley, and J. W. Doran. 1997. Nutrient, carbon, and mass loss during composting of beef cattle feedlot manure. J. Environ. Qual. 26:189.

El Kader, N. A., P. Robin, J. M. Paillat, and P. Leterme. 2007. Turning, compacting and the addition of water as factors affecting gaseous emissions in farm manure composting. Bioresour. Technol. 98:2619.

Erickson, G. E., and T. J. Klopfenstein. 2001. Managing $\mathrm{N}$ inputs and the effect on $\mathrm{N}$ losses following excretion in open-dirt feedlots in Nebraska. ScientificWorldJournal 1(Suppl. 2):830.

Erickson, G. E., T. J. Klopfenstein, W. Luedtke, M. Schroeder, C. Francis, and G. Lesoing. 2001. Composting of feedlot and dairy manure: compost characteristics and impact on crop yields. Nebraska Beef Cattle Rep. MP 76-A:92.
Freeze, B. S., J. T. Heigh, F. J. Larney, and A. F. Olson. 1999. Economics of windrow composting and land application of manure. p. 311 in Proc. Manure Management 1999 Saskatoon, SK.

Hao, X., C. Chang, and F. J. Larney. 2004. Carbon, nitrogen balances and greenhouse gas emission during cattle feedlot manure composting. J. Environ. Qual. 33:37.

Hao, X., C. Chang, F. J. Larney, and G. R. Travis. 2001. Greenhouse gas emissions during cattle feedlot manure composting. J. Environ. Qual. 30:376.

Helgason, B. L., F. J. Larney, and H. H. Janzen. 2005. Estimating carbon retention in soils amended with composted beef cattle manure. Can. J. Soil Sci. 85:39.

Kirchmann, H., and E. Witter. 1989. Ammonia volatilization during aerobic and anaerobic manure decomposition. Plant Soil 115:35.

Kissinger, W. F., G. E. Erickson, and T. J. Klopfenstein. 2006. Summary of manure amounts, characteristics, and nitrogen mass balance for open feedlot pens in summer and winter feeding periods. J. Anim. Sci. 84(Suppl. 2):102.

Klopfenstein, T. J., and G. E. Erickson. 2002 Effects of manipulating protein and phosphorus nutrition of feedlot cattle on nutrient management and the environment. J. Anim. Sci. 80(E. Suppl. 2):E106

Larney, F. J., and R. E. Blackshaw. 2003. Weed seed viability in composted beef cattle feedlot manure. J. Environ. Qual. 32:1105.

Larney, F. J., and K. E. Buckley. 2007. Dry matter mass balance estimates for composted feedlot manure. Compost Sci. Util. 15:222.

Larney, F. J., K. E. Buckley, X. Hao, and P. McCaughey. 2006. Fresh, stockpiled, and composted beef cattle feedlot manure: Nutrient levels and mass balance estimates in Alberta and Manitoba. J. Environ. Qual. $35: 1844$.

Larney, F. J., A. F. Olson, P. R. DeMaere, B. P. Handered, and B. C. Tovell. 2008a. Nutrient and trace element changes during manure composting at four southern Alberta feedlots. Can. J. Soil Sci. 88:45.

Larney, F. J., A. F. Olson, J. J. Miller, P. R. DeMaere, F. Zvomuya, and T. A. McAllister. 2008b. Physical and chemical changes during composting of wood chip-bedded and straw-bedded beef cattle feedlot manure. J. Environ. Qual. 37:725.
Lesoing, G., T. Klopfenstein, D. Duncan, and M. Schroeder. 1997. Composting of feedlot waste-update of research activities. Nebraska Beef Cattle Rep. MP 67-A:88.

Littell, R. C., P. R. Henry, and C. B. Ammerman. 1998. Statistical analysis of repeated measures data using the SAS procedures. J. Anim. Sci. 76:1216.

Meisinger, J. J., and W. E. Jokela. 2000. Ammonia volatilization from dairy and poultry manure. p. 334 in Managing Nutrients and Pathogens from Animal Agriculture. Natural Resource, Agriculture, and Engineering Service, Ithaca, NY. NRAES-130.

NRCS (National Resources Conservation Service). 1992. Composting. Part 637 in Agricultural Waste Management Field Handbook. Accessed Feb. 5, 2009. http://www.wsi. nrcs.usda.gov/products/W2Q/AWM/docs/ neh637c2.pdf

Parkinson, R., P. Gibbs, S. Burchett, and T. Misselbrook. 2004. Effect of turning and seasonal weather conditions on nitrogen and phosphorus losses during aerobic composting of cattle manure. Bioresour. Technol. 91:171.

Sharpley, A., and B. Moyer. 2000. Phosphorus forms in manure and compost and their release during simulated rainfall. J. Environ. Qual. 29:1462.

Shiralipour, A., D. B. McConnell, and W. H. Smith. 1997. Phytotoxic effects of a short chain fatty acid on seed germination and root length of Cucumis sativus cv. 'Poinset'. Compost Sci. Util. 5:47.

Thomsen, I. K. 2000. C and N transformations in $15 \mathrm{~N}$ cross-labelled solid ruminant manure during anaerobic and aerobic storage. Bioresour. Technol. 72:267.

Wilson, C. B., G. E. Erickson, T. J. Klopfenstein, W. Luedtke, and M. A. Schroeder. 2005. Composting of feedlot manure: Compost characteristics, crop yields and application rates. Nebraska Beef Cattle Rep. MP 83-A:57.

Wortmann, C. S., and D. T. Walters. 2006. Phosphorus runoff during four years following composted manure application. J. Environ. Qual. 35:651.

Zvomuya, F., F. J. Larney, C. K. Nichol, A. F. Olson, J. J. Miller, and P. R. DeMaere. 2005. Chemical and physical changes following co-composting of beef cattle feedlot manure with phosphogypsum. J. Environ. Qual. 34:2318. 